УДК: 658.155 .2

Тітенко 3.М., к.е.н. старший викладач

Пастушенко А.В., студентка

Національний університет біоресурсів і природокористування України

\title{
ПРОБЛЕМИ ФОРМУВАННЯ ТА ВИКОРИСТАННЯ ФІНАНСОВИХ РЕСУРСІВ ПІДПРИЕМСТВ
}

У статті досліджено особливості формування фінансових ресурсів в умовах нестабільної економіки. Проаналізована структура фінансових ресурсів підприємств України та фінансові результати їх діяльності за останні роки. Визначено частку збиткових підприємств та проаналізовано причину неефективної їх діяльності. Запропоновано шляхи покращення формування та використання фінансових ресурсів.

Ключові слова: фінансові ресурси, власні кошти, залучений капітал, формування, використання.

Titenko Z., Pastushenko A.

\section{PROBLEMS OF FORMATION AND EFFICIENT USE OF FINANCIAL RESOURCES}

The peculiarities of financial resources formation in the conditions of unstable economy are investigated in the article. The structure of financial resources of Ukrainian enterprises and the financial results of their activity in recent years are analyzed. The share of unprofitable enterprises is determined and the reason for their ineffective activity is analyzed. Proposed ways to improve the formation and use of financial resources.

Keywords: financial resources, own funds, raised capital, formation, use.

Титенко 3.Н., Пастушенко А.В.

\section{ПРОБЛЕМЫ ФОРМИРОВАНИЯ И ИСПОЛЬЗОВАНИЯ ФИНАНСОВЫХ РЕСУРСОВ ПРЕДПРИЯТИЙ}

В статье иследовано особенности формирования финансовых ресурсов в условиях нестабильной экономики. Проанализирована структура финансовых ресурсов предприятий Украины и финансовые результаты их деятельности за последние годы. Определена доля убыточных предприятий и проанализированы причины неэффективной их деятельности. Предложены пути улучшения формирования и использования финансовых ресурсов.

Ключевые слова: финансовые ресурсы, собственные средства, привлеченный капитал, формирование, использование.

Постановка проблеми у загальному вигляді i iї зв'язок з важливими науковими та практичними завданнями. Нестабільність національної валюти, розгортання інфляційних процесів, недосконалість бюджетно-податкової політики, скорочення власних ресурсів через збиткову діяльність, недоступність кредитних ресурсів через їх високу вартість, загострення економічної та політичної кризи та інші фактори здійснюють негативний вплив на ефективність господарської діяльності підприємств України.

Розвиток ринкових відносин в Україні відбувався на тлі постійної нестачі фінансових ресурсів у значної кількості суб'єктів підприємницької діяльності. Відсутність фінансових ресурсів у необхідному обсязі спричинює порушення платіжної дисципліни та зниження рівня фінансової стійкості підприємств, а отже, і національної економіки.

Аналіз останніх досліджень у яких започатковано вирішення проблеми. Дослідженню проблем, пов'язаних із формуванням фінансових ресурсів підприємств, присвятили свої праці багато вітчизняних та зарубіжних вчених зокрема, це Бланк I.А., Козачок I.А., Лондар С.Л., Нестеренко Н.В., Пилипенко О.О., Поддєрьогін А.М., Рудченко I.В., Терещенко О.О. 
Цілі статті. Метою даної статті $є$ дослідження особливостей формування фінансових ресурсів вітчизняних підприємств в умовах сучасної нестабільної економічної ситуації, що склалася в Україні.

Виклад основного матеріалу дослідження 3 новими обгрунтуванням отриманих наукових результатів. В українській економічній думці на сьогодні існує багато підходів до визначення економічної сутності фінансових ресурсів підприємства. Проте варто відмітити, що переважає визначення фінансових ресурсів, яке відображає сукупність грошових доходів та нагромаджень, які забезпечують виконання фінансових зобов'язань, покриття поточних витрат та забезпечення соціально-економічного розвитку підприємства. Серед науковців, що досліджували поняття «фінансові ресурси», не існує єдиної думки, щодо сутності даного поняття. Зокрема Моляков Д.С. стверджує, що фінансові ресурси - це грошові кошти, що знаходяться в розпорядженні держави, підприємств, господарських організацій i установ та які використовуються для фінансування витрат та утворення різних фондів та резервів [1, с. 17]. I.А. Бланк, розглядає фінансові ресурси, як сукупність акумульованих власних і позикових коштів та їх еквівалентів у формі цільових грошових фондів, призначених для забезпечення його господарської діяльності в майбутньому періоді [2, с.20].

B.М. Опарін стверджує, що фінансовими ресурсами підприємства можна вважати сукупність грошових фондів цільового призначення, сформованих у процесі розподілу і перерозподілу валового внутрішнього продукту, створеного на підприємстві, якими воно розпоряджається на правах власності або повного господарського відання і використовує на статутні потреби. [3, с. 15]. У визначенні I.I. Бронської, на нашу думку, наведено комплексний та узагальнений підсумок всіх попередніх визначень [4, с. 12]. Отже, він стверджує, що фінансові ресурси підприємства - це грошові кошти, які $\epsilon$ в розпорядженні підприємства і призначені для здійснення поточних витрат і витрат із розширеного відтворення, для виконання фінансових зобов'язань i економічного стимулювання працівників

Фінансові ресурси підприємств поділяються на власні, залучені та позичені кошти. Власні формуються в результаті внутрішніх грошових потоків у вигляді чистого доходу та зовнішніх - вкладів засновників, безоплатної фінансової допомоги. Залучені кошти підприємство отримує як відстрочку платежу за окремими видами зобов'язань. Позичені кошти підприємство отримує у вигляді позик фінансово-кредитних установ або на фінансовому ринку.

Отже, аналізуючи обсяг фінансових ресурсів визначено поступове їх зростання. так в порівняні з 2012 роком їх обсяг зріс на 73\% і в 2017 році склав 9961779,1 млн. грн. Варто відмітити і негативну динаміку, зокрема у 2017 році відбулося незначне зменшення фінансових ресурсів на $1 \%$.

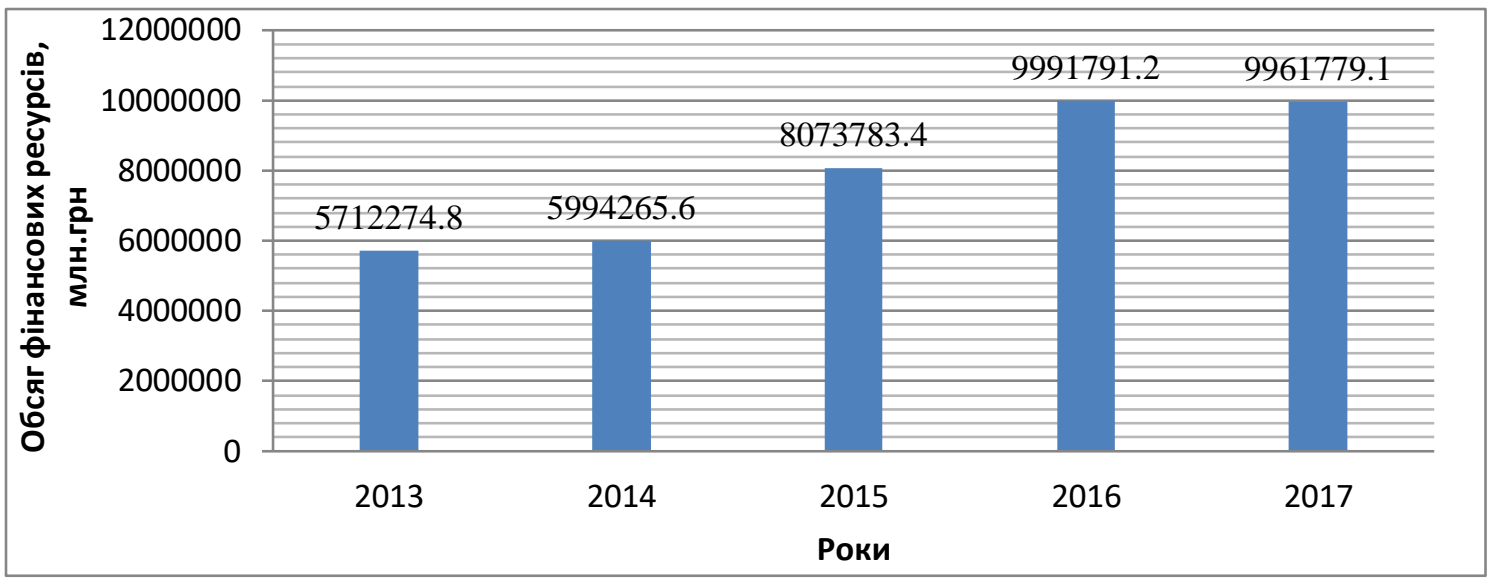

Рис.1 Динаміка фінансових ресурсів, млн. грн

Джерело сформовано автором на основі [5] 


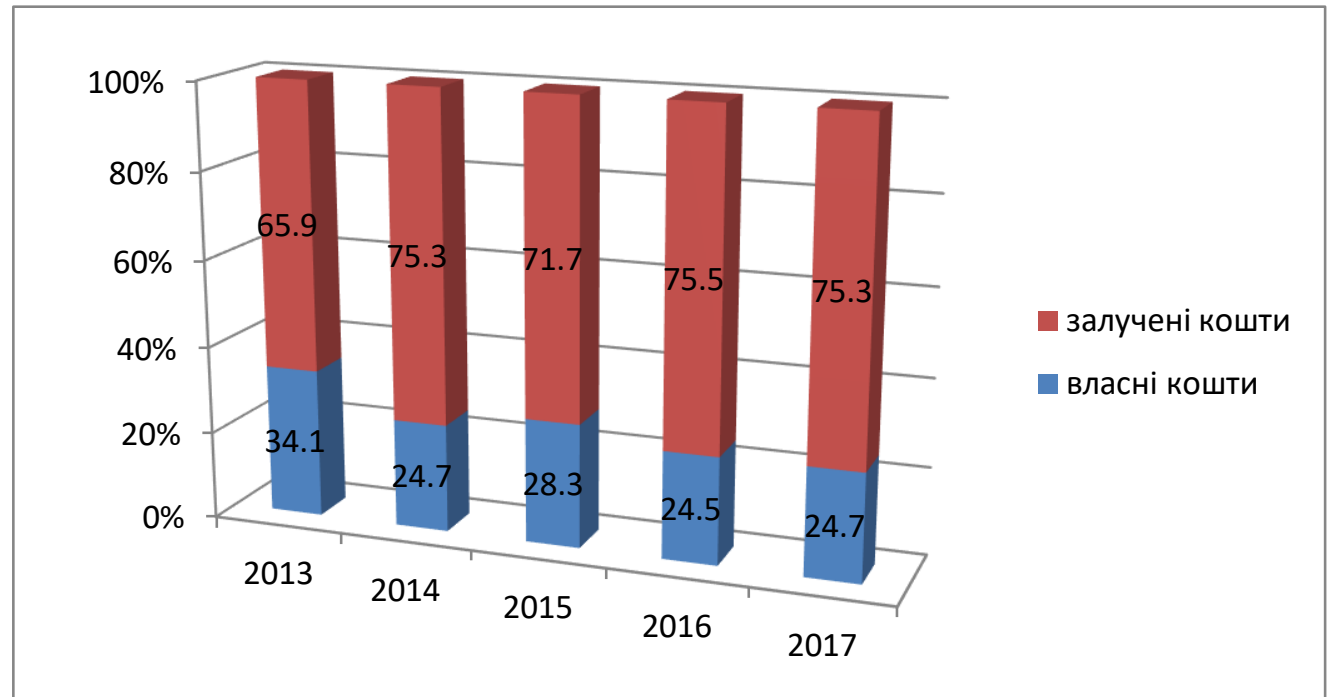

Рис.2 Структура фінансових ресурсів підприємств України, 2013-2017pp.

Джерело розраховано автором на основі [5]

Фінансові ресурси обслуговують усі сфери виробництва і в національній економіці розосереджені по відповідних галузях. Дослідження свідчить, що найбільше їх в промисловості, а саме 31,6\% від загальної кількості, це пояснюється тим, що дана галузь забезпечує економіку країни сировиною і продовольством, значну частку також займає оптова та роздрібна торгівля - 20,1\%. Найменша частка фінансових ресурсів зосереджена в галузях охорони здоров'я та мистецтва,спорту,розваг та відпочинку лише $0,2 \%$.

Співвідношення між власними та позичковими коштами є показником структури капіталу, одним і з найголовніших критеріїв оцінки фінансового стану підприємства. Підвищення частки власних коштів має позитивний вплив на фінансово-господарську діяльність підприємства. А висока частка позичкових коштів вимагає додаткові витрати (сплата відсотків за використання кредитів, виплата дивідендів, процентів по облігаціям), які зменшують фінансову стійкість, ліквідність та платоспроможність

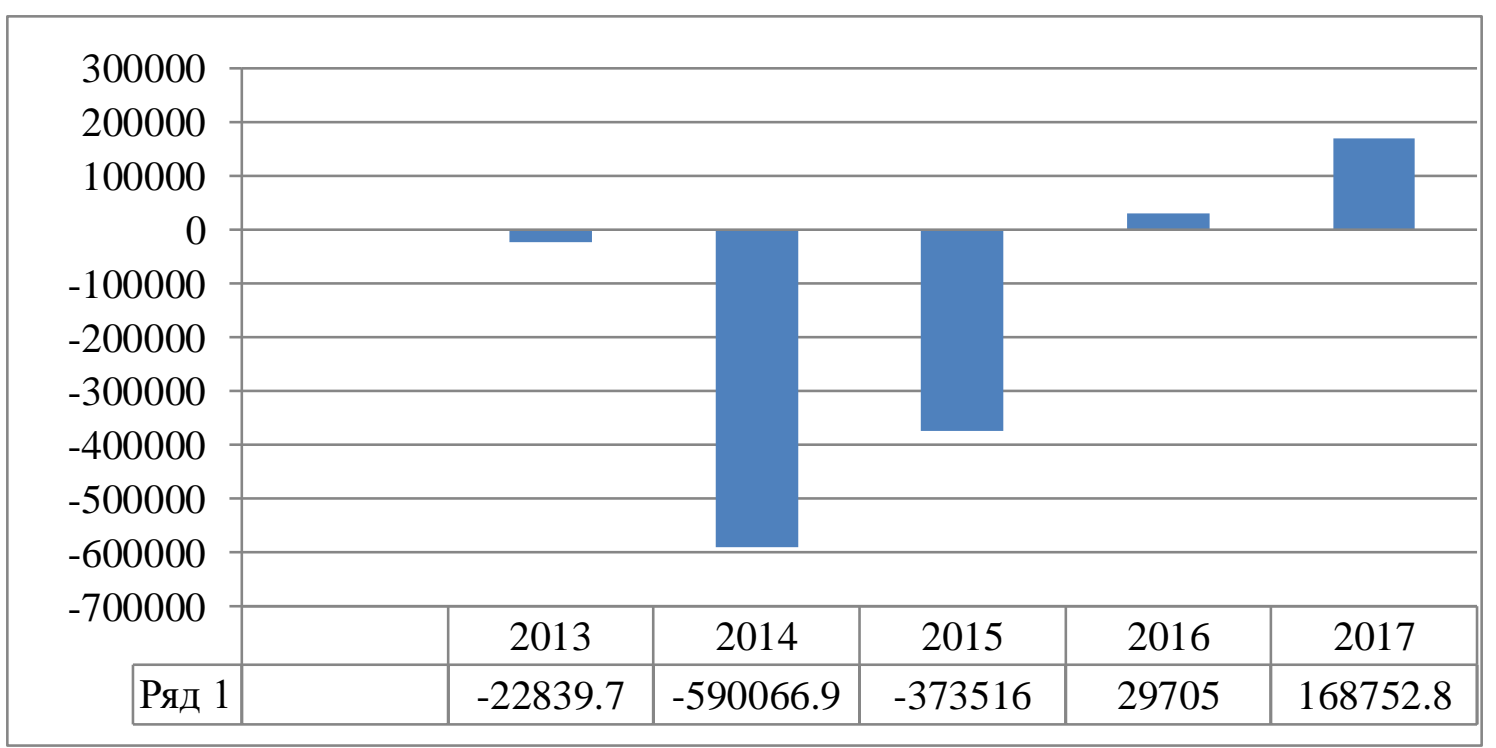

Рис.3. Фінансовий результат від звичайної діяльності до оподаткування, 20132017 pp., млн. грн

Джерело сформовано автором на основі [5] 


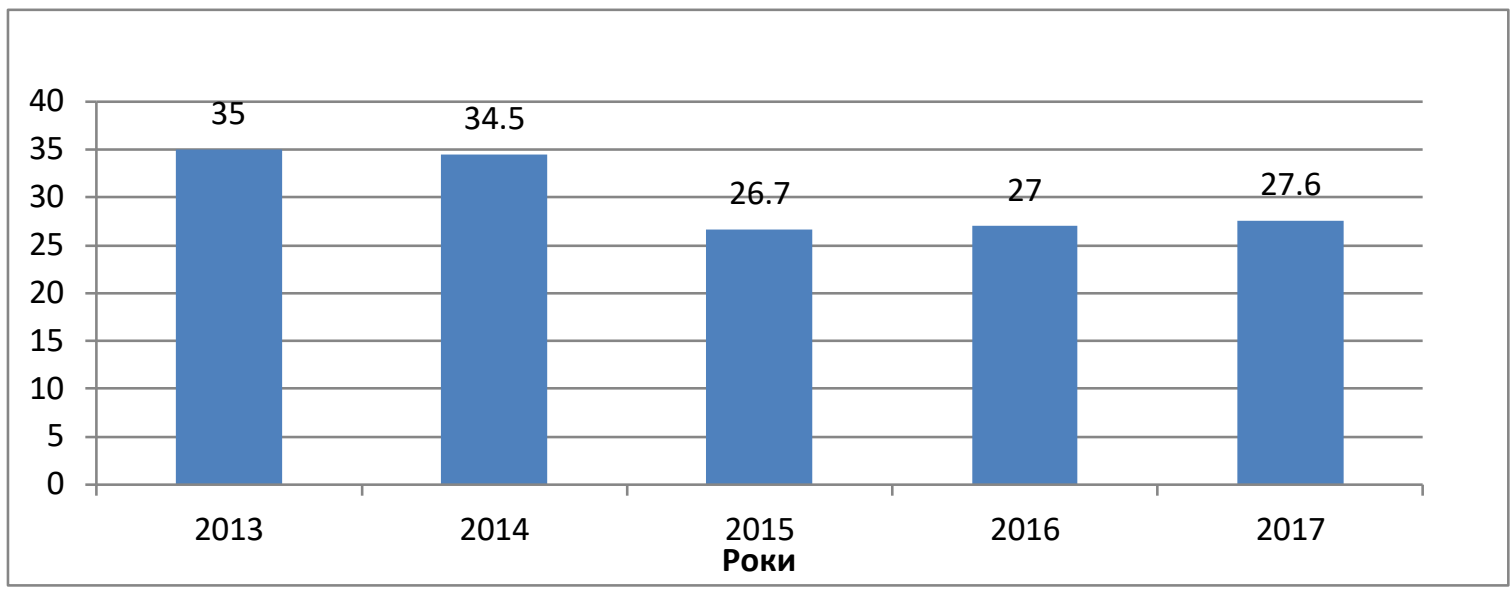

Рис.4 Частка збиткових підприємств в Україні 2013-2017p.p

Джерело сформовано автором на основі [5]

підприємства. Структуру фінансових ресурсів підприємств наочно відображає, яку ж частку займають власні кошти, а яку - позичкові у загальній структурі фінансових ресурсів підприємств України.

Аналіз структури фінансових ресурсів підприємств України за 2013-2017 рр. свідчить, що протягом досліджуваного періоду зберігалася тенденція зростання частки залучених коштів. Так, у 2017 році в порівнянні з 2013 роком їх частка зросла на 9,4\% і склала 75,3.

В Україні частка власних фінансових ресурсів має тенденцію до зниження. Підприємства використовують ці кошти для рефінансування діяльності, покращення матеріальної бази, забезпечення розширеного відтворення. Для своєї поточної виробничо-фінансової діяльності підприємства все більше користуються позиками та залученими коштами, Це говорить про те, що підприємства все частіше функціонують за рахунок позичкових коштів.

Система фінансових ресурсів України потребує позитивних реформувань для ефективного їх використання, адже наявність позикових коштів змушує підприємства сплачувати додаткові проценти за використання кредитів, коли, наприклад, ці кошти можна було б направити на розширення свого виробництва [6, с.44].

Потрібно розуміти, що для оцінки стану підприємств не достатньо лише даних структури фінансових ресурсів, оскільки вони не відображають рівень ефективності їх використання та функціонування підприємства в цілому. Для цього варто проаналізувати фінансовий результат (рис.3,4), який отримують підприємства, та порівняти зі структурою фінансових ресурсів. Якщо фінансовий результат має позитивне значення, це свідчить про те, що підприємство має змогу брати позичкові кошти, розраховуватися зі зобов'язаннями, та при всьому цьому мати дохід (прибуток).

Аналіз фінансових результатів від звичайної діяльності свідчить проте, що в 2014 році відбулося різке зниження фінансового результату, що свідчить про недостатню кількість фінансових ресурсів для ефективного ведення фінансово-господарської діяльності підприємств. Проте в динаміці ми спостерігаємо поступове покращення фінансових результатів, і варто відмітити, що у 2016 році підприємства отримали прибуток 29705 млн. грн., а в 2017 році він зріс до168752,8 млн грн., це свідчить, про раціональне використання власних коштів та можливість залучення позичкових зі змогою сплати процентів за користування кредитами у майбутньому. Такі умови позитивно впливають на впровадження інновацій та інвестицій.

Незважаючи на позитивні зрушення в діяльності підприємств, на сьогодні залишається досить велика кількість збиткових підприємств (рис4). 
Отже, на сьогодні частка збиткових підприємств становить 27,6\% від загальної їх кількості, проте потрібно відмітити і позитивну динаміку оскільки в останні роки прослідковується тенденція до їх зменшення. Так, з 2013 року їх частка зменшилася на 7,4 відсоткових пункти. Одним із факторів, що негативно впливає на кінцеві результати діяльності є забезпечення підприємств достатньою кількістю фінансових ресурсів. Варто відмітити, що підприємства не завжди реально оцінюють спроможність нести зобов'язання за використання залучених коштів, а також визначити оптимальне співвідношення між власними та позичковими коштами для досягнення позитивного результату їх діяльності.

Для раціонального формування та ефективного використання фінансових ресурсів підприємствам потрібно враховувати ряд рекомендацій: У тактичному аспекті: притримуватися необхідного рівня платоспроможності та ліквідності для покриття поточних зобов'язань, ефективно використовувати фінансові ресурси, проводити постійний контроль та моніторинг виробничої та збутової діяльності для забезпечення достатнього рівня рентабельності. У стратегічному аспекті: визначення та дотримання оптимальної структури власних та залучених коштів, що забезпечить платоспроможності підприємства у довгостроковій перспективі.

На формування та використання фінансових ресурсів підприємства мають вплив різноманітні чинники [7], як зовнішнього, так і внутрішнього середовища. Зокрема, до внутрішніх варто віднести: організацію управління фінансовими ресурсами; забезпечення зв'язку збуту з виробництвом; аналіз ринку продукції; якість фінансового, податкового, управлінського обліку; цінова політика, аналіз цін конкурентів. Основними факторами зовнішнього середовища $\epsilon$ інфляція; нормативно-правове регулювання діяльності; політичний та економічний стан країни.

Висновоки. На сьогодні потужний негативний вплив на ефективність використання фінансових ресурсів мають фактори кризового стану економіки, що існують незалежно від дій підприємства. Водночас підприємства мають внутрішні резерви підвищення ефективності їх використання, на які вони можуть впливати. Одним з головних чинників організації управління фінансовими ресурсами $\epsilon$ ефективна робота фінансового менеджера щодо використання та формування фінансових ресурсів на ефективному рівні. Фінансові ресурси є основою функціонування підприємств різних галузей. При їх правильному формуванні та використанні в умовах нестабільної економічної ситуації в Україні, фінансові ресурси будуть забезпечувати безперервне виробництво і функціонування підприємств.

\section{Список бібліографічного опису:}

1. Моляков Д. С. Фінанси підприємств галузей народного господарства. К.: Фінанси і статистика, 2000. С. 200

2. Бланк I. А. Фінансовий менеджмент. К.: Ельга, Ніка-Центр, 2005. С. 649

3. . Опарін В. М. Фінансові ресурси та суспільний капітал. Вісник НБУ. 2001. № 7. С. 26-28

4. Бродська І.І. Проблеми формування фінансових ресурсів підприємств. Економічні науки. 2010. Вип. 7(25). Ч. 1. С. $182-189$.

5. Статистичний щорічник України. Режим доступу: http://www.ukrstat.gov.ua/.

6. Домбровська С. О. Тенденції системи формування фінансових ресурсів підприємств України та шляхи іiі вдосконалення. Науковий вісник Одеського національного економічного університету. 2015. № 2 (222). С. $42-54$.

7. Бражник Л.В. Фінансові ресурси підприємства: їх формування та використання Економіка та суспільство. 2018. № 14. С. $778-783$.

\section{References:}

1. Molyakov D. S. (2000) Finansy` pidpry`yemstv galuzej narodnogo gospodarstva [Finances of enterprises of branches of national economy]. K.: Finansy`i staty`sty`ka [Finances and statistics], [in Ukrainian].

2. Blank I. A. (2005) Finansovy`j menedzhment [Financial Management]. K.: El`ga, Nika-Centr, [in Ukrainian].

3. . Oparin V. M. (2001) Finansovi resursy` ta suspil`ny`j kapital [Financial resources and social capital]. Visny`k NBU [Bulletin of the National Bank of Ukraine]. № 7. S. 26-28 [in Ukrainian].

4. Brods`ka I.I.(2010) Problemy` formuvannya finansovy`x resursiv pidpry`yemstv [Problems of formation of financial resources of enterprises.]. Ekonomichni nauky` [ Economic sciences.]. V. 7(25). Ch. 1. S. 182-189. [in Ukrainian].

5. Staty`sty`chny`j shhorichny`k Ukrayiny`[ Statistical Yearbook of Ukraine]. Access mode: http://www.ukrstat.gov.ua/.

6. Dombrovs`ka S. O. (2015) Tendenciyi sy`stemy` formuvannya finansovy`x resursiv pidpry`yemstv Ukray iny` ta shlyaxy` yiyi vdoskonalennya [Tendencies of the system of formation of financial resources of Ukrainian enterprises and ways of its improvement.]. Naukovy`j visny`k Odes`kogo nacional`nogo ekonomichnogo universy`tetu [Scientific Bulletin of the Odessa National Economic University]. № 2 (222). S. 42-54.

7. Brazhny`k L.V. (2018) Finansovi resursy` pidpry`yemstva: yix formuvannya ta vy`kory`stannya [Financial resources of the enterprise: their formation and use] Ekonomika ta suspil`stvo [Economy and society.]. № 14. S. 778-783. 